\title{
Service Quality of Organizations Providing Long- Term Social Care
}

\author{
Jolita Geciene, (MBA) \\ Agota Giedre Raisiene, (PhD., Professor) \\ Mykolas Romeris University, Lithuania
}

\begin{abstract}
The article presents an evaluation of social care quality following the EQUASS methodology. The evaluation was carried out considering the aspects of institutional care reform and factors of intersectoral collaboration and partnership between organizations providing social services which are important for the spread of good practice, more effective institution management and optimization of state resource use. In addition, the article discusses the requirements for social care institutions' service quality, analyzes the main models for service quality assessment applied in Lithuania and the EU. The research has shown that based on the evaluation of research subjects, the social care institutions' service quality is quite high. The quality of services could be improved by eliminating the weaknesses of intersectoral collaboration.
\end{abstract}

Keywords: Social service, quality, EQUASS, organization management, collaboration.

\section{Introduction}

The relevance of the article is related to the state level reform of social care services. The reform is expected to change institutional care with services provided in the community.

Social care homes evaluate their service compliance with social care norms every year. The main standard that defines the criteria for social service quality and provision of social services is the Description of the Social Security Regulations of the Republic of Lithuania (2007). However, it should be noted that the current system of social service quality assessment heavily emphasizes the indicators of objective (technological) evaluation scale while the use of subjective scale is valued less. The quality of social services is often assessed in the aspects of their rationality, efficiency and cheapness which does not necessarily ensure the life quality of people receiving the services. 
The results of a research by Araujo and Ceolim (2007) confirm that the level of independence of institutionalized elderly people is decreasing. Research by Roszmann et al. (2014) determined that care institutions satisfy the physical and medical needs of their inhabitants but leave psychological and social needs aside. Due to this reason, development of various quality assessment models was started. Unfortunately, most of the models are rarely or never applied in Lithuania.

On the abovementioned relevance, the goal of the article is formed: to analyze the results of qualitative evaluation of long-term social care providing organizations" service quality carried out following the EQUASS methodology.

Although the social care system and quality of services was examined by many scientists in the world, the number of researches based on a qualitative methodological approach is low in Lithuania while SERVQUAL model mentioned earlier was not invoked in any research.

During the research, theoretical (analysis, comparison) and empirical (questionnaire survey) methods were invoked. Questionnaire prepared following EQUASS methodology was used as an instrument for gathering empirical data. The analysis of research data was carried out using data processing software SPSS. Specific effectiveness indicators of social care institutions' service quality were calculated following the quality principles of EQUASS: leadership, personnel, partnership and continuous improvement.

\section{Challenges of public sector effectiveness}

The management reforms taking place require public institutions to take on new challenges in work planning, decision making, realization and coordination in all areas of resource management (Raipa, 2009). The society demands effectiveness of public sector institutions, new forms of activity and continuously improving quality indicators. Thus, the importance of relationship between service providers and consumers, organizational changes in public sector structures and innovations in project, information, technology, finance and human resource management constantly rises (Puškorius, Raipa, 2002).

The possibilities of public sector activity effectiveness are firstly comprehended as providing services of a higher quality using the same resources. According to Raipa (2009), considering the modern public management reforms, the interaction between knowledge, experience, comprehension of politics and decision making is mandatory. The main participants of this interaction are organizations of public and private sectors however, they sometimes include societal - non-governmental organizations into management improvement. Bindham (2009) emphasizes that although intersectoral and interorganizational collaboration results seem quite good in 
general, they are worse in public sector due to a complicated process. Researches on intersectoral and interinstitutional collaboration show that partners often understand collaboration as a way to reach their goals or solve their problems. Therefore, it is important to find solutions which would allow to ensure sustainability on a wider scale: in dimensions of social life, environment and economic effectiveness (Borges at al., 2016). Common goal that unites organization is the essential cause for the initialization of intersectoral collaboration (Raišienè, Baranauskaite, 2018). The vision of partners should coincide while common goal should differ from goals of separate members of interaction. The goal of collaboration should be clearly defined and properly communicated (Olson et al. 2011). In addition, partners should be oriented to long-term goals because setting short-term goals and results does not form interrelations between the member organizations and does not strengthen mutual trust (Grossmann, 2012).

The main criteria for collaboration success, according to Grossmann (2012) are: organization of collaboration as an independent system; concentration to partners' skills and competences; evaluation of people and the possible influence of their interpersonal relations; setting common activity aspects; comprehension of joint benefits; creation of control system; correct management of collaboration process; creation of internal requirements (rules); ensuring effective teamwork; coordination of different interests and opinions; mutual trust. Partners' mutual trust is considered and undisputable foundation of collaboration.

Finally, Perrault et al., (2011) discusses the quality of partner relations and states that collaboration is a long-term relationship, based on which separate organizations create new common structures and share common resources. Thus, rational coordination of public and private institution and structure activity in providing more qualitative services and public products would help social service companies in pursuing the improvement of social life standards.

According to Bitinas et al. (2010), the current tendencies in public administration show that social services are improving when citizens are involved on a wider scale and principles of subsidiarity, transparency, accountability, impartiality, accessibility, collaboration and effectiveness preside.

Hence, the changes taking place in modern society related to decreasing number of inhabitants, aging of society and peculiarities of social change and management require the coordination of public sector (including social care institutions) activity on an interinstitutional and intersectoral level and horizontal and vertical interorganizational relationships based on partnership. 


\section{The necessity of social service quality improvement in the context of public sector effectiveness}

Lately, social service provision is treated anew in public sector. Nowadays, "services are no longer comprehended as "unilateral" processes because consumers and other members of society have an increasing role in decision making and realization" (Raipa, Petukienè, 2009, p.54).

According to McDonald, Harris and Wintersteen (2003) it could be stated that qualitative social services require high qualification of social workers and high expenses, thus, only organizations that provide services with lower resources persist in the market, usually at the expense of quality. An altered system of social work services includes various service organizations which work on a level of municipalities, solving local problems. Funds dedicated to social work services are managed by municipalities that are responsible for ensuring well-being of local communities, organization of required services and collaboration with various social work service organizations.

One of the most important aspects of social service system is the content of social services. When reforming social, education and health services, a tendency of integration is noticeable which aims to improve the effectiveness of public service sector and implement intersectoral integration.

The European, including Lithuanian citizens are aging. Along with the aging society, changing health, social and economic conditions, life quality priorities change as well. With these changes in mind, the goals of social policy should change too. Research by Spirgiene et al. (2010) has shown that social care institutions lack a unified assessment system for social and everyday activity. Social care institutions assess the compliance of provided services with the social protection regulations. However, in the opinion of the authors, it is insufficient. Research by Rozsmann et al. (2014) determined that the majority of physical and medical needs of social care institution inhabitants are satisfied, however, psychological and social needs are often left unsatisfied. According to Žalimienè (2007), one of reliable ways to ensure the quality of services is standardization, i.e. application of legally consolidated requirements to the quality of services. The necessity to prepare and apply social service standards is cause by both the orientation of service system to better satisfying the needs of the customer and the pursuit to rationalize the structure of service organization.

In summary, it can be stated that the level of independence of elderly people living in care institutions decreases. To avoid this, requirements applied to services provided by social care institutions should be increased. The first step is assessing the current quality of services. 


\section{Models for the assessment of public sector organization service quality}

The increasing expectations of public sector organizations' clients and citizens stimulate the organizations to make changes, adapt to new challenges and seek to constantly improve their service quality. As Adomaityte Subačienè (2015) states, quality is an essential goal in providing social services due to several reasons. Firstly, the consumers of social services are usually members of a vulnerable group with a limited ability to take care of themselves and make decisions. Following the fundamental values of the EU and international conventions ratified in Lithuania, it is mandatory to monitor the provision of services to ensure the rights of vulnerable groups and to improve quality of services. Secondly, social services are funded by the government or municipalities. Thus, when the state's ability to fund social services decreases, it becomes of vital importance for the funds to be used effectively. The internal management of organizations and employee policy formation is important too. Furthermore, for social work sphere to attract employees that are creative, enterprising, able to critically think and make decisions, the attractiveness of social service sector has to be increased. Effective quality management can greatly contribute to these goals.

Various models of quality assessment that help the European public sector organizations to use quality management methods to improve their work are already being used in Lithuania as well, including: European Foundation for Quality Management (EFQM) model; General Evaluation Model (GEM); Service Quality (SERVQUAL) model and the European Quality System for Social Services (EQUASS).

In 1992, the European Foundation for Quality Management (EFQM) model of perfection was introduced. The EFQM model is based on a holistic approach of the organization and is oriented to consumers and continuous improvement of all organizational processes by including all employees. This model acknowledges that human resources are the opportunities that allow to achieve results while processes are used as tools to release and use the organization's potential (Žèkienè, 2014). Although the EFQM model is accepted as a valuable tool for forming quality culture in an institution, one of the authors of the model Conti (2007) claims that the full benefit of the model is gained only if internal self-analysis and external evaluation are carried out and actions of improvement are taken upon.

Another model - the General Evaluation Model (GEM) is a result of collaboration between the ministers of the EU, responsible for public administration. By the request of general managers of this area, the Innovative Public Services Group (IPSG) prepared a version of GEM. GEM is a simple, easily applied and appropriate method for self-evaluation of public sector organizations. GEM was created to be applied in the whole public sector in public sector organizations on a regional, national and local levels. It can be 
applied in various circumstances, for example as a part of systemic program of a reform or as a basis to determine the development directions for civil service organizations. The main advantage of GEM is justified evaluation, where the method shows relationships between goals, strategies and processes and allows to determine the level of progress and achievements. However, it should be emphasized that GEM is a tool for self-evaluation and formally applying the model does not ensure better work results.

The SERVQUAL method was created for business companies to evaluate the quality of services they provide to their clients. This method of service quality assessment assumes that the client evaluates the quality of services by comparing the expected quality of services with the one they receive. At first, the client is asked to evaluate, how important is the quality factor and later he is asked to evaluate how that same criterion is fulfilled by the services received. SERVQUAL was prepared by Zeithaml, Parasuraman and Berry (1990) in an attempt to evaluate quality in production. The authors divide the structure of SERVQUAL into five parts which the clients treat as most important to the quality of services: tangibility, reliability, responsibility, assurance and sensitivity. Applying this method in practice requires adapting the research method to the specifics of a particular organization's work and its clients.

The European Quality System for Social Services (EQUASS) is an initiative of the European platform of rehabilitation. Currently EQUASS is accepted in the EU member states as the most appropriate system for social sector as the quality principles of this system best meet the expectations of clients receiving rehabilitation, vocational training or social services. Programs of EQUASS provide versatile services in areas of service quality improvement, encouragement, acknowledgement and certification which follow the European requirements for social services. The system is customized to the social sector and offers a versatile attitude based on specific quality criteria, work effectiveness indicators, clear external evaluation and audit procedures (EQUASS, 2017). EQUASS includes 10 principles of quality which are formed by consulting with social sector stakeholders are based on the European System for Social Service Quality Assurance and general values of the society (EQUASS, 2012), such as leadership, personnel, rights, ethics, partnership, participation, orientation to an individual, complexity, orientation to results, continuous improvement. Every quality principle is divided into smaller quality criteria. Specific work efficiency indicators show work efficiency reached by following the quality criteria (EQUASS, 2017). The EQUASS Assurance trademark guarantees the quality of service provision by approving compliance with 50 criteria based on quality principles. These criteria include essential elements of quality management system which are applied in the social sector. 
The superiority of EQUASS quality system is that its quality principles basically correspond with the principles and criteria of Common Quality Framework for Social Services of General Interest and European Quality Assurance in Vocational Education and Training (EQAVET), is oriented to satisfying the needs of consumers, society and other stakeholders. Thus, EQUASS can be applied to ensure, assess, measure and improve the quality of social services inseparable part of white are vocational rehabilitation services (Disability High Level Group, 2007).

Having analyzed the models of service quality assessment, it becomes clear that EQUASS is one of the most appropriate methods for this task. EQUASS Assurance is adapted to social sector and offers an attitude based on quality criteria and main activity indicators using a self-evaluation questionnaire.

\section{Research methodology}

To analyze the quality of services provided by social care institutions, a quantitative research following EQUASS method was conducted. The data of the research were obtained using a questionnaire survey. The institutions are not named in the article to retain confidentiality.

The sample of the research - employees of Lithuanian social care institutions providing long-term and/or short-term social care services. The employees were distributed following the list of social service area positions including: social care home managers, social workers, social worker assistants, employment specialists. A total of 341 respondent participated in the survey: 105 institution managers, 122 social workers, 36 employment specialists and 78 social worker assistants.

To determine the statistical significance of differences by position, the following criteria were invoked:

1) ANOVA - single-factor dispersion analysis was used to compare the averages of several independent samples. An F criterion was calculated for this difference (dispersion ratio). Dispersion analysis or F criterion is applied only to compare the averages of more than two populations when data is provided in an interval scale, distributed by normal distribution and is of three or more independent samples (Čekanavičius, Murauskas, 2002).

2) Chi-squared criterion when data is expressed in a ranking or nominal scale. According to Pakalniškienè (2012), chi-squared is an evaluation of a null hypothesis, which shows that the model fits the data perfectly.

The data of the research was analyzed using a data analysis tool SPSS (Statistical Package for Social Sciences) and Microsoft Office Excel 2007.

The data in the article is visualized using diagrams and tables. 


\section{Research results and discussion}

Via research result analysis, the authors of the article reveal the spread of answers in different subscales of statements.

To ensure integration into the society, the social service provider must act in partnership with other institutions providing social services. Partnership collaboration principle is defined by the Law of Social Services X-493 (2006) which states that management, designation and provision of social services is based on the collaboration and mutual help of an individual, family, society, organizations protecting the interests and rights of social groups, municipalities and governmental institutions.

Table 1 illustrates the spread of "Partnership" statements. In general, the respondents agreed with the statement "Division I work in works in partnership with external organizations" the most (64.2 percent) while the statement that was agreed with the least was "I am familiar with how my organization develops partnership with profit or non-profit organizations or public sector organizations" (56.3 percent). Based on the respondents' answers and assumption could be made that partnership in social care institutions is either not developed effectively or the employees are not properly informed about it. Comparing the spread of answers by respondents of different positions, it is obvious that answers differed significantly $(\mathrm{p}<$ 0.05 ) between the two statements, thus, respondents of different positions evaluated the statements with significant difference. This result of the survey is important in evaluating the quality of services as partnership and collaboration enables sharing good practice, improving work results and improving the quality of services. Therefore, it is important to have a good understanding of partnership realization and collaboration organization processes and principles.

Table 1. Statements in the "Partnership" subscale, in percent.

\begin{tabular}{|c|c|c|c|c|c|c|c|}
\hline \multirow[b]{2}{*}{ Statement } & \multicolumn{4}{|c|}{ Respondents } & \multirow[b]{2}{*}{$\chi^{2 *}$} & \multirow[b]{2}{*}{$\begin{array}{l}d \\
f\end{array}$} & \multirow[b]{2}{*}{$p$} \\
\hline & $\begin{array}{l}\stackrel{\Xi}{0} \\
\stackrel{0}{\Xi} \\
\stackrel{\Xi}{\Xi}\end{array}$ & 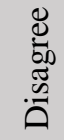 & 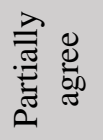 & $\begin{array}{l}\stackrel{\Xi}{\Xi} \\
\frac{0}{4}\end{array}$ & & & \\
\hline $\begin{array}{c}\text { I am familiar with how my } \\
\text { organization develops partnership } \\
\text { with profit or non-profit organizations } \\
\text { or public sector organizations }\end{array}$ & 10,0 & 6,5 & 27,3 & 56,3 & 76,495 & 9 & 0,000 \\
\hline $\begin{array}{l}\text { Division I work in works in } \\
\text { partnership with external } \\
\text { organizations }\end{array}$ & 9,1 & 6,2 & 20,5 & 64,2 & 58,832 & 9 & $\mathbf{0 , 0 0 0}$ \\
\hline
\end{tabular}

Statistically significant (when $\mathrm{p}<0.05$ ) differences are highlighted, $\chi^{2} *_{\text {- }}$ Chi-squared criterion, $\mathrm{df}$ - degrees of freedom of the criterion, $\mathrm{p}$ - statistical significance of the criterion.

Source: authors. 
The commitments of institution's leader, realization of institution's goals, ensuring good management and work conditions, leadership and social responsibility all have impact on the quality of social services provided. The principle of leadership covers all these areas. Table 2 presents the spread of answers to statements in the "Leadership" subscale which shows that the respondents mostly agreed with the statement "I am familiar with the vision, mission and values of our organization" (98.2 percent) and agreed with the statement "I am familiar with the procedures of hiring and retaining personnel" least (61.6 percent). It could be stated that the leaders of institutions have an understanding about the criteria of principle of leadership and implement them well because the positive answers to all statements are over 70.5 percent.

Social workers and employment specialists are less familiar with the procedures of hiring and retaining personnel (47.5 and 33.3 percent respectively). Meanwhile, social worker assistants are least committed to help social service receivers to integrate into the society (48.7 percent).

Comparing the spread of answers by respondents of different positions, in almost all cases answers differed significantly $(\mathrm{p}<0.05)$ which shows that different statements are evaluated significantly differently by respondents of different positions. The Law of Social Services (2006) states that social service management includes planning and organizing social services, distributing competences and evaluating and supervising the quality of social services on municipality or state levels. Based on the respondents ${ }^{6}$ answers it could be stated that the provider of social services accomplishes its organization's mission, vision and values, ensures good management, leadership, quality policy, process of annual planning, follows health and safety requirements and is compliant with requirements of the Law of Social Services.

Table 2. Statements in the "Leadership" subscale, in percent.

\begin{tabular}{|c|c|c|c|c|c|c|c|}
\hline \multirow[b]{2}{*}{ Statement } & \multicolumn{4}{|c|}{ Respondents } & \multirow[t]{2}{*}{$\chi^{2 *}$} & \multirow[t]{2}{*}{$d$} & \multirow[t]{2}{*}{$p$} \\
\hline & 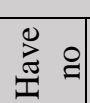 & 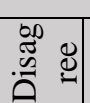 & 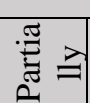 & 总 & & & \\
\hline $\begin{array}{l}\text { I am familiar with the vision, mission and } \\
\text { values of our organization. }\end{array}$ & 0,6 & 0,0 & 1,2 & 98,2 & 10,963 & 6 & 0,090 \\
\hline $\begin{array}{l}\text { I contribute to the realization of our } \\
\text { vision, mission and values in my everyday } \\
\text { work. }\end{array}$ & 0,0 & 0,6 & 4,7 & 94,7 & 15,626 & 6 & 0,016 \\
\hline $\begin{array}{l}\text { I am familiar with the quality } \\
\text { requirements for everyday work. }\end{array}$ & 0,6 & 0,0 & 5,9 & 93,5 & 18,588 & 6 & 0,005 \\
\hline $\begin{array}{c}\text { We work in an ordinary way in our } \\
\text { organization in order to ensure that our } \\
\text { work meets the service quality } \\
\text { requirements. }\end{array}$ & 0,9 & 0,0 & 7,0 & 92,1 & 33,567 & 6 & 0,000 \\
\hline $\begin{array}{l}\text { I have a clear understanding of the goals } \\
\text { of our annual plan and activity it intends. }\end{array}$ & 0,6 & 1,5 & 8,2 & 89,7 & 53,684 & 9 & 0,000 \\
\hline
\end{tabular}




\begin{tabular}{|c|c|c|c|c|c|c|c|}
\hline $\begin{array}{c}\text { I contribute to the realization of } \\
\text { organization's annual plan goals in my } \\
\text { everyday work. }\end{array}$ & 0,0 & 1,5 & 7,9 & 90,6 & $\mathbf{5 6 , 1 6 3}$ & $\mathbf{6}$ & $\mathbf{0 , 0 0 0}$ \\
\hline $\begin{array}{c}\text { Leaders show commitment to integrate } \\
\text { the people receiving services into the } \\
\text { society. }\end{array}$ & 0,0 & 3,8 & 22,9 & 73,3 & $\mathbf{1 5 , 2 1 6}$ & $\mathbf{6}$ & $\mathbf{0 , 0 1 9}$ \\
\hline $\begin{array}{c}\text { I am personally committed to integrate } \\
\text { the people receiving services into the } \\
\text { society. }\end{array}$ & 0,3 & 5,0 & 30,8 & 63,9 & $\mathbf{2 1 , 2 3 7}$ & $\mathbf{9}$ & $\mathbf{0 , 0 1 2}$ \\
\hline $\begin{array}{c}\text { The leaders' behavior clearly shows that } \\
\text { they are committed to execute the } \\
\text { institution's social responsibility. }\end{array}$ & 1,2 & 1,8 & 9,7 & 87,4 & $\mathbf{5 9 , 7 8 9}$ & $\mathbf{9}$ & $\mathbf{0 , 0 0 0}$ \\
\hline $\begin{array}{c}\text { I am personally committed to execute the } \\
\text { institution's social responsibility. }\end{array}$ & 0,0 & 0,0 & 12,3 & 87,7 & $\mathbf{2 4 , 8 8 6}$ & $\mathbf{3}$ & $\mathbf{0 , 0 0 0}$ \\
\hline $\begin{array}{c}\text { I am familiar with the procedures of } \\
\text { hiring and retaining personnel. }\end{array}$ & 3,2 & 4,1 & 31,1 & 61,6 & $\mathbf{7 6 , 7 9 5}$ & $\mathbf{9}$ & $\mathbf{0 , 0 0 0}$ \\
\hline $\begin{array}{c}\text { I am familiar with health and work safety } \\
\text { requirements. }\end{array}$ & 0,9 & 0,0 & 5,3 & 93,8 & $\mathbf{3 1 , 0 8 5}$ & $\mathbf{6}$ & $\mathbf{0 , 0 0 0}$ \\
\hline $\begin{array}{c}\text { I am familiar with the working condition } \\
\text { (order) requirements in my organization. }\end{array}$ & 1,8 & 0,6 & 4,1 & 93,5 & $\mathbf{5 0 , 1 7 1}$ & $\mathbf{9}$ & $\mathbf{0 , 0 0 0}$ \\
\hline My working conditions are appropriate. & 1,5 & 0,6 & 17,6 & 80,4 & $\mathbf{2 1 , 1 0 6}$ & $\mathbf{9}$ & $\mathbf{0 , 0 1 2}$ \\
\hline
\end{tabular}

Statistically significant (when $\mathrm{p}<0.05$ ) differences are highlighted, $\chi^{2} *_{\text {- }}$ Chi-squared criterion, $\mathrm{df}$ - degrees of freedom of the criterion, $\mathrm{p}$ - statistical significance of the criterion.

Source: authors.

The quality of provided services is influenced by the workers ${ }^{6}$ qualification, dutifulness, initiative and motivation. The spread of answers to the "Personnel" subscale (Table 3) reveals that in general, the respondents agreed with the statement "I am familiar with my duties and functions" most (98.2 percent) while statement "My leaders actively stimulate the satisfaction and motivation of the personnel" was agreed on the least (66 percent). Institution leaders and social workers least agreed with the statement "I am satisfied with my job; my work motivates me" (73.3 and 47.5 percent respectively) while the statement that employment specialists and social worker assistants agreed with the least was "My leaders actively stimulate the satisfaction and motivation of the personnel" (50 and 76.9 percent respectively).

Comparing the spread of answers of respondents of different positions, the answers differed significantly in all cases ( $\mathrm{p}<0.05$ ), which shows that separate statements were evaluated significantly differently by respondents of different positions. Based on the respondents' answers, it can be stated that social care institutions apply means of personnel qualification improvement, employees are familiar with their duties and functions. The description for improving competences of workers in social service area (2006) directs to motivating workers to seek higher professional competence and improve competences that would help to achieve the best work results. 
The answers of the respondents also reveal that there is a lack of means for motivating employees.

Table 3. Statements in the "Personnel" subscale, in percent

\begin{tabular}{|c|c|c|c|c|c|c|c|}
\hline \multirow{2}{*}{ Statement } & \multicolumn{4}{|c|}{ Respondents } & \multirow[b]{2}{*}{$\chi^{2} *$} & \multirow[b]{2}{*}{$\begin{array}{l}d \\
f\end{array}$} & \multirow[b]{2}{*}{$p$} \\
\hline & 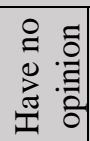 & 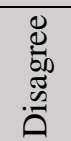 & 尝 8 & 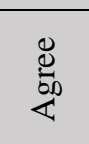 & & & \\
\hline $\begin{array}{l}\text { I am familiar with the content of personnel } \\
\text { qualification improvement plan. }\end{array}$ & 0,6 & 3,2 & 15,0 & 81,2 & $\mathbf{7 8 , 5 9 7}$ & 9 & $\mathbf{0 , 0 0 0}$ \\
\hline $\begin{array}{c}\text { The personnel qualification improvement } \\
\text { plan reflects my learning and improvement } \\
\text { needs. }\end{array}$ & 2,3 & 1,8 & 21,7 & 74,2 & 51,846 & 9 & $\mathbf{0 , 0 0 0}$ \\
\hline $\begin{array}{l}\text { We regularly review the personnel } \\
\text { qualification improvement plan. }\end{array}$ & 2,9 & 5,3 & 19 & 72,4 & 44,618 & 9 & $\mathbf{0 , 0 0 0}$ \\
\hline I am familiar with my duties and functions. & 0,0 & 0,0 & 1,8 & 98,2 & 10,963 & 3 & $\mathbf{0 , 0 1 2}$ \\
\hline $\begin{array}{c}\text { I actively participate in improvement } \\
\text { initiatives. }\end{array}$ & 3,2 & 1,5 & 10,3 & 85,0 & 36,997 & 9 & $\mathbf{0 , 0 0 0}$ \\
\hline I actively participate in creating new services. & 1,8 & 3,2 & 14,1 & 80,9 & 77,825 & 9 & 0,000 \\
\hline $\begin{array}{l}\text { My leaders actively stimulate the satisfaction } \\
\text { and motivation of the personnel }\end{array}$ & 0,6 & 4,1 & 29,3 & 66,0 & 43,553 & 9 & 0,000 \\
\hline $\begin{array}{l}\text { I am satisfied with my job; my work } \\
\text { motivates me. }\end{array}$ & 0,6 & 4,1 & 29,0 & 66,3 & 43,279 & 9 & 0,000 \\
\hline
\end{tabular}

Statistically significant (when $\mathrm{p}<0.05$ ) differences are highlighted, $\chi^{2} *_{\text {- }}$ Chi-squared criterion, $\mathrm{df}$ - degrees of freedom of the criterion, $\mathrm{p}$ - statistical significance of the criterion.

Source: authors.

Pursuing to reach high quality of provided services, it is important to constantly improve service provision and work organization. The spread of answers to statements in the "Continuous improvement" subscale shows that the respondents mostly agreed with the statement "The organization I work in indicates the expectations of stakeholders that are related to creation and improvement of our services" (76 percent) while statement "I am familiar with the ways to determine the stakeholder expectations related to creation and improvement of our services" was agreed on the least (68.3 percent). Opinions on this question diverge. Although answers do not differ significantly, it can be seen that institution leaders, social workers and social worker assistants agree with the statement „I am familiar with the ways to determine the stakeholder expectations related to creation and improvement of our services" the least (Table 4). However, employment specialists agree with this statement the most (77.8 percent). Comparing the answers by respondents of different positions it can be seen that the answers differed significantly $(\mathrm{p}<0.05)$. 
Table 4. Statements in the "Continuous improvement" subscale, in percent.

\begin{tabular}{|c|c|c|c|c|c|c|c|}
\hline \multirow[b]{2}{*}{ Statement } & \multicolumn{4}{|c|}{ Respondents } & \multirow[b]{2}{*}{$\chi^{2} *$} & \multirow[b]{2}{*}{$\begin{array}{l}d \\
f\end{array}$} & \multirow[b]{2}{*}{$p$} \\
\hline & 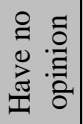 & 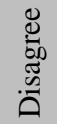 & 蔦 & 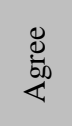 & & & \\
\hline $\begin{array}{l}\text { I am familiar with the ways of improving } \\
\text { my division's work. }\end{array}$ & 0,6 & 1,8 & 23,8 & 73,9 & 75,544 & 9 & $\begin{array}{c}0,00 \\
0\end{array}$ \\
\hline $\begin{array}{l}\text { Organization I work in indicates the } \\
\text { stakeholder expectations related to the } \\
\text { creation and improvement of our services. }\end{array}$ & 2,3 & 1,2 & 20,5 & 76,0 & 54,996 & 9 & $\begin{array}{c}\mathbf{0 , 0 0} \\
\mathbf{0}\end{array}$ \\
\hline $\begin{array}{l}\text { I am familiar with the way to determine } \\
\text { stakeholder expectations related to the } \\
\text { creation and improvement of our services. }\end{array}$ & 1,8 & 1,2 & 28,7 & 68,3 & 18,411 & 9 & $\begin{array}{c}0,03 \\
1\end{array}$ \\
\hline
\end{tabular}

Statistically significant (when $\mathrm{p}<0.05$ ) differences are highlighted, $\chi^{2} *_{\text {- Chi-squared }}$ criterion, $\mathrm{df}$ - degrees of freedom of the criterion, $\mathrm{p}$ - statistical significance of the criterion.

Source: authors.

The general theoretical limits of service quality of social care institutions are 0 to 100 . However, according to the results of this research, this scale fits into the range of 9.55 to 100 .

Comparing the evaluation of the general level of service quality by respondents of different positions it was determined that the quality is evaluated best by the leaders of the institutions (average 88.08, standard deviation 18.98), social worker assistants (average 88.00, standard deviation 20.00) and social workers (average 83.03, standard deviation 23.43. However, ANOVA test did not determine any significant differences (because $\mathrm{F}=1,405$, $\mathrm{p}=0,241>0,05)$ which shows that workers of different positions evaluate the quality of social services they provide similarly (Figure 1). Thus, following the EQUASS mode for quality assessment, workers of different positions evaluate different quality indicators similarly.

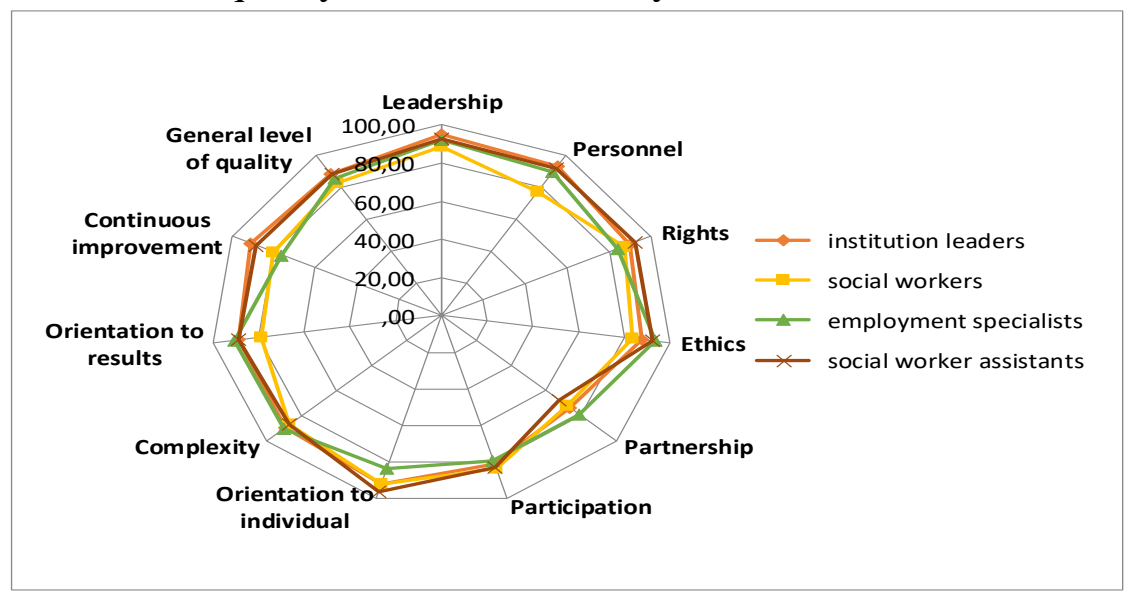

Figure 1. Averages of service quality subscales by work position. Source: authors. 
Summing the results of the research up it can be noticed that EQUASS quality evaluation system allowed to reveal how qualitatively the services are provided in a given area. The research determined that the general level of service quality in social care institutions is quite high.

\section{Conclusion}

The research has shown that the services of public sector organizations providing long-term social care are of quite high-quality judging by subjective evaluation of their employees. The principle of leadership is evaluated the highest, the leaders have the best understanding about it and execute all its criteria. A bit lower evaluation is that of personnel management and continuous improvement. The results of respondents ${ }^{6}$ answers revealed that leaders should be more active in stimulating employees' satisfaction and motivation. In addition, the quality of provided services must be continuously improved with the aim to best satisfy the needs of care home inhabitants and their relatives. The criteria of partnership principle are evaluated as least important. The research determined that implementation of partnership principle should include informing employees about partnership with other institutions and collaborating with external organizations. Employees of different positions evaluate the quality of provided services similarly, the answer indicators differ insignificantly. General and special services are evaluated as good or very good by most of the respondents.

However, it should be stated that intersectoral and interinstitutional collaboration was evaluated moderately during the research. Due to answers being significantly different after being grouped on the criteria of respondent's position, it can be stated that leaders of institutions are informed better than specialists. This result also shows that interinstitutional collaboration is more of a strategic - advisory nature rather than practice-applied. As a result, the possibilities for institutions to share good practice, more effectively solve common problems and manage state and organizational resources decrease.

\section{References:}

1. Adomaitytė-Subačienė, I. (2015). Socialinių paslaugų kokybès standartizavimas Lietuvoje. Socialine teorija, empirija, politika ir praktika, 11, 54-63.

2. Araujo, M., \& Ceolim, M. (2007). Assessment of the level of independence of elderly residents in long-term care institutions, $R e v$ Esc Enferm USP, 41(3), 378-385.

3. Bindham, L.B. (2009). Collaborative Governance: Emerging Practices and Incomplete legal Framework for Public and Stakeholder Voice, Missouri Journal of Dispute Resolution, 2, 269-326. 
4. Borges, M.A., Soares, A.L., \& Dandolini, G.A. (2016). Collaborative Networks as Ways to Improve Cross-sector Collaboration in Social Innovation: An Exploratory Study. Federal University of Santa Catarina.

5. Čekanavičius, V., \& Murauskas, G. (2002). Statistika ir jos taikymai. Vilnius, VU.

6. Conti, T. A. (2007). The History of the European Quality Award Model: a Useful Perspective for a Critical Analysis of its Strengths and Limits. Quality Management and Organizational Development, 18-20, Lund University, Helsingborg.

7. Disability High Level Group (2007). Quality of social services of general interest (SSGI), Brussels.

8. EQUASS, (2012). EQUASS Assurance procedūros. European Quality for Social Services (EQUASS).

9. EQUASS, (2017). 2018 m. EQUASS Assurance ženklo pripažinimo principai, kriterijai ir rodikliai. EQUASS, Brussels.

10. Grossmann, R., Lobnig, H., Scala, K., \& Stadlober, M. (2012). Facilitating Collaboration in Public Management, Information Age Publishing, p. 219, Bentley University.

11. Lietuvos Respublikos socialinès apsaugos ir darbo ministro icsakymas Nr. A1-46. (2007). „Dèl Socialinès globos normu aprašo patvirtinimo “. Valstybès žinios, 24-(931).

12. Lietuvos Respublikos Seimas. Lietuvos Respublikos socialiniu paslaugu istatymas Nr. X-493. (2006). Valstybès žinios, 17-(589).

13. McDonald, C., Harris, J., \& Wintersteen, R. (2003). Contingent on Context? Social Work and the State in Australia, Britain and the USA. The British Journal of Social Work, 33(2),191-208.

14. Olson, C.A., Balmer, J.T., \& Mejicano, R.G.C. (2011). Factors contributing to successful interorganizational collaboration: The case of CS2day. Journal of Continuing Education in the Health professions. 31 (S1): S12.

15. Pakalniškienè, V. (2012). Tyrimo ir ịvertinimo priemoniu patikimumo ir validumo nustatymas. Vilnius, VU.

16. Perrault, E., McClelland, R., Austin,C., \& Sieppert, J. (2011). Working Together in Collaborations: Successful Process Factors for Community Collaboration. Administration in Social Work, 35 (3), 282298.

17. Puškorius, S., \& Raipa, A. (2002). Teoriniai viešojo sektoriaus veiklos modernizavimo aspektai. Viě̌oji politika ir administravimas, 2, 9-17.

18. Raipa, A. (2009). Šiuolaikinio viešojo valdymo pokyčių kryptys ir tendencijos. Viešoji politika ir administravimas, 30, 22-32. 
19. Raipa, A., \& Petukienė, E. (2009). Klientų dalyvavimas viešosiose paslaugose: bendrasis paslaugu kūrimas. Viešoji politika ir administravimas, 27, 54-62.

20. Raišienè, A.G., \& Baranauskaitė, L. (2018). Investigating Complexity of Intersectoral Collaboration: Contextual Framework for Research. Contemporary Research on Management and Administration. 6 (1), 79-89.

21. Roszmann, A., Žuralska, R., Sitek, E., Slawek, J., Skrzypek-Czerko, M., Domagala, P., \& Mziray, M. (2014). Needs assessment of long term care institutions residents with dementia. Acta Neuropsychologica. 12 (1), 65-72.

22. Spirgienė, L., Macijauskienè, J., \& Spirgys, A. (2010). Gyventoju socialinès ir kasdienès veiklos sąsajų vertinimas ilgalaikès globos institucijose. Gerontologija 11(4), 199-203).

23. Žalimienè, L. (2007). Socialinès globos paslaugų pagyvenusiems žmonėms standartizavimas: Lietuvos praktika ir užsienio šalių patirtis. Gerontologija. 8 (1), 44-54).

24. Zeithaml, V. A., Parasuraman, A., \& Berry, L. (1990). Delivering quality service: Balancing customer perceptions and expectations, New York: Free Press.

25. Žèkienè, A. (2014). Vadybos tobulumo modelis. Kvalitetas EFQM. 